\title{
A Framework for Analyzing Intergovernmental Collaboration
}

\section{- The Case of ASEAN Tourism}

\author{
by Emma P.Y. Wong, Nina Mistilis, Larry Dwyer
}

University of New South Wales, Australia

\section{ABSTRACT}

Intergovernmental collaboration in tourism among ASEAN nations has received little attention in the literature despite the significant contribution that tourism makes in the region. This paper helps to improve our understanding of the phenomenon by providing an overview of the progress made since 2002, and exploring the factors that facilitated and hindered progress. It was found that many of the suggested measures in the action plan, Roadmap for Integration of Tourism Sector, were either not implemented at all or overdue, although relatively significant progress was made in travel facilitation and human resources development. The authors suggest that current theories of collaboration do not adequately explain that of ASEAN tourism. They expand the boundaries of theory by presenting a framework of collaboration which dissects the facilitators and inhibitors along three dimensions - stakeholders, resources, and processes and mechanisms. Recommendations to expedite and strengthen the collaboration are then formulated. 
KEYWORDS: Intergovernmental collaboration; ASEAN; Tourism Agreement

\section{Introduction}

Despite the continuous cooperative endeavour among ASEAN (Association of Southeast Asian Nations) member nations and the significant contribution tourism makes in the region, there are very few studies that examine ASEAN tourism collaboration. The majority of existing studies that are related to ASEAN economic cooperation deal with general framework agreements, namely ASEAN Free Trade Agreement (AFTA) and ASEAN Framework Agreement on Services (AFAS). Collaboration in specific economic sectors is overlooked by researchers.

ASEAN was established as a means of maintaining peace and stability in Southeast Asia by providing a forum for the discussion and resolution of regional issues which had the potential to destabilize the region. Five countries officially formed the Association on 8 August 1967: Indonesia, Malaysia, the Philippines, Singapore and Thailand. Together with Brunei, which joined on 8 January 1984, the six countries are also known as ASEAN-6. 
With the fall of Communism in Eastern Europe and the end of the Cold War, there was no longer a pressing need for ASEAN countries to fear their Communist neighbors such as Vietnam, Cambodia and Laos. These countries had started to abandon central planning and implement market-oriented economic reforms since the early 1980s, changes which implicated trade and investment opportunities and indicated that ASEAN regional grouping needed to be enlarged to maintain relevance.

The momentum to expand ASEAN was further accelerated by the need to strengthen the region's voice in international trading bodies such as APEC (the Asia-Pacific Economic Cooperation forum), the World Trade Organization, and in negotiations with the European Union (Tan, 2003). Between 1995 and 1997, Cambodia, Laos, Myanmar and Vietnam (CLMV) joined ASEAN. They are sometimes referred to as newer members with less- developed economies.

The long-term goal of ASEAN is to establish a free trade area in Southeast Asia (Yeh, 2002). While ASEAN's economic emphasis has most often focused on trade in manufactured goods, minerals and fuels, tourism has grown to become an important consideration, in large part due to the rapid growth of the industry in the region 
(Timothy, 2003).

ASEAN tourism is forecast to continue to grow. In 2008, the region received 65.5 million visitors, almost doubled the figure in 2002 (33 million arrivals) (UNWTO, 2003; ASEAN, 2009a). According to UNWTO, the Southeast Asian region is expected to experience an average annual growth rate of $6.3 \%$ between 1995 and 2020 . By 2020, the regional arrival figure is projected to reach 136 million per annum (UNWTO, 2000)

- illustrating the growing importance of tourism for and the interdependence among ASEAN nations.

Table 1 shows the contribution of travel and tourism to individual ASEAN members' GDP. While the real regional GDP growth for the tourism sector from 2009 to 2010 is $-2.1 \%$ (perhaps associated with the 2008-09 global financial crisis), tourism makes a significant contribution to the ASEAN economy, $11 \%$ of the region's GDP.

(Insert Table 1 here) 
Each supranational organization forms and operates in a specific context, which comprises both facilitators and inhibitors of the organization success. Often, existing theories cannot fully explain the various interactions within these organizations or their relative influence on outcomes. Using ASEAN tourism as a case study, the authors identified the unique features of this collaboration. These findings not only help expand the boundaries of existing theories and thus contribute to the literature, but also provide input into improving ASEAN tourism policies, which in turn has the potential to enhance the contribution of tourism to the development of the region.

This study examines the progress made by ASEAN since the inception of the ASEAN Tourism Agreement in 2002 and the corresponding action plan Roadmap for Integration of Tourism Sector in 2004. It is important for both researchers and policy-makers to learn from the journey so far and identify what has facilitated and hindered the progress. The paper assesses progress and presents a new framework that dissects the inhibiting and facilitating factors of collaboration.

This paper has three major objectives:

1. To provide an overall assessment of the progress made thus far in ASEAN 
tourism collaboration.

2. To identify the factors that have facilitated and hindered collaboration in ASEAN tourism.

3. To provide policy recommendations to strengthen the collaboration process in ASEAN to develop tourism in the region.

\section{Case study}

To identify the factors that facilitate ASEAN collaboration in tourism and barriers to success, the authors adopted a case approach. Case study is deemed appropriate in examining contemporary events when the relevant behaviors cannot be manipulated. The case approach deals with evidence collected from direct observation of events and interviews of people involved (Yin, 2003). Considering the fact that the current research concerns a contemporary social phenomenon that cannot be manipulated by researchers, case study is an appropriate research strategy for this research.

Various sources of evidence were used in this study, including official documents from ASEAN, non-official publications (e.g. academic journals, books, newspapers and trade magazines), and interviews with key stakeholders involved. The use of multiple sources 
allowed data triangulation and thus enhanced the credibility and dependability of findings (Lincoln and Guba, 1985).

In-depth interviews were conducted in January to March 2005 and January to February 2006. A total of twenty-two face-to-face and telephone interviews were administered and two email responses received. Twenty-one individuals took part in the study, three of whom were interviewed twice. Among the twenty-one participants, thirteen were high-level government officials, representing nine out of the ten ASEAN member countries. The other eight represented international organizations (e.g. ASEAN Secretariat; Asian Development Bank), industry associations (e.g. ASEAN Tourism Association; Pacific Asia Travel Association), and academia or consultancies (e.g. Institute of Southeast Asia Studies; Sustainable Tourism Cooperative Research Centre).

All data were inputted into the software NVivo 2.0 for analysis. NVivo is a data management and analytical tool which not only facilitates coding of data, but its searching and modeling tools also enable researchers to confirm propositions and to explore new relationships embedded in the data. The basic underlying logic is that, ideas expressed in the data are broken down into simple "units" of concepts and the 
software can illustrate the relationships among selected concepts in tabular or graphical formats.

\section{Findings}

\subsection{Assessment of ASEAN tourism collaboration progress}

Powell (1994) argues that the effectiveness and resilience of an international regime, such as ASEAN, are the underlying factors for evaluating regime significance. A regime is effective to the extent that its members abide by its norms and rules, and that it fulfils its goals by enhancing cooperation in the issue area(s) (Underdal, 1992; Young, 1994; Hasenclever et al., 1997). Regime resilience refers to the "staying power" of international institutions in the face of exogenous challenges and to the extent to which prior institutional choices constrain collective decisions and behavior in later periods (Powell, 1994:341). In other words, institutions that change with every shift of power among their members or whenever the most powerful participants find that their interests are no longer served by the current regime, lack resilience (Hasenclever et al., 1997). The concept of regime effectiveness can be applied here to evaluate the progress of ASEAN tourism, i.e. the extent to which the members abide by the rules and that the objectives are fulfilled. Later in Section 3.2.1, it is claimed that the change of leadership, 
and the subsequent change of priorities in governments has contributed to the lack of progress in ASEAN tourism. Such change is what Powell would refer to as the lack of regime resilience.

Current ASEAN tourism collaboration is undertaken based on the policy framework set out by the 2002 ASEAN Tourism Agreement. The Agreement contains seven objectives (ASEAN, 2002):

(1) To cooperate in facilitating travel into and within ASEAN.

(2) To enhance cooperation in the tourism industry among ASEAN member states in order to improve its efficiency and competitiveness.

(3) To substantially reduce restrictions to trade in tourism and travel services among ASEAN member states.

(4) To establish an integrated network of tourism and travel services in order to maximize the complementary nature of the region's tourist attractions.

(5) To enhance the development and promotion of ASEAN as a single tourism destination with world-class standards, facilities and attractions.

(6) To enhance mutual assistance in human resource development and strengthen cooperation to develop, upgrade and expand tourism and travel facilities and 
services in ASEAN.

(7) To create favourable conditions for the public and private sectors to engage more deeply in tourism development, intra-ASEAN travel and investment in tourism services and facilities.

In 2004, the Roadmap for Integration of Tourism Sector was introduced by the ASEAN Economic Ministers (AEM) to serve as an action plan for implementing the seven agreement objectives. The integration exercise across various economic sectors is envisioned to be completed by 2015 in an attempt to establish the ASEAN Economic Community (ASEAN, 2006). This section provides an overview of the progress made by ASEAN for the measures proposed in the Roadmap. It evaluates the extent to which targets are achieved and whether or not deadlines are met as set out in the action plan.

It was found that among the seven objectives, significant progress was made in only two, namely, Objective 1 - facilitating travel, and Objective 6 - human resources development. To facilitate travel within the region, a Framework Agreement on Visa Exemption was signed among the members in 2006. It allows ASEAN nationals to travel within the region without a visa for two-weeks. This is a very important step 
towards liberalizing the flow of money and people within the region.

To strengthen human resources development, a project to develop common competency standards was completed in 2008. It is a system established to standardize the vocational competency requirements for 33 job titles. It means that skills and qualifications acquired in one country would be readily recognized by other member states, and in turn facilitates the movement of tourism workers in the region. The standards would also serve as benchmarks for countries to identify areas in which they have fallen short and more training is required. This helps lay the foundation for future competitiveness enhancement efforts.

(Insert Table 2 here)

Table 2 provides a snapshot of the progress made in ASEAN tourism. It is structured according to the seven Agreement Objectives categorized into three broad themes. Wong et al (in press) suggest that the objectives can be thematized into three general aims: 1) to liberalize the flow of money and people in the region (Objectives 1, 3 and 4); 2) to increase the competitiveness of the tourism industry (Objectives 2 and 6); and 3) to 
strengthen the unity and identity of ASEAN as a region (Objectives 4 and 5). The most significant achievements are listed in the last column.

The table shows that no Agreement objectives have been fully met. In terms of facilitating travel (Objective 1) and engaging public and private sectors (Objective 3), progress was marked by the 2006 Visa Exemption Framework Agreement, and Investment Forum which started in 2005 respectively. No significant outcome can be found for the trade restriction reduction objective (Objective 7). In terms of enhancing human resource development (Objective 6), progress was made with Common Competency Standards finalized in 2008. Yet, there is no evidence to show improvement in industry efficiency and competitiveness (Objective 2). In the area of promoting ASEAN as a single destination (Objective 5), joint promotion in trade shows started in 2006. No progress was identified for an integrated network of tourism services (Objective 4).

Our assessment of ASEAN tourism indicates a lack of progress where many of the measures suggested in the Roadmap were either not implemented at all or overdue. In reference to Powell's (1994) concept of regime effectiveness, ASEAN tourism is not 
effective in abiding to its rules and fulfilling its goal to enhance cooperation in issue areas. From a management perspective, this can be attributed to the ill-defined objectives and measures. Some concepts stated in the Agreement are vague, for example industry "efficiency and competitiveness" in Objective 2, and "integrated network of services" in Objective 4. Motherhood statements were found in some of the measures proposed in the Roadmap, which have little contribution to implementation of tourism collaboration. For instance, to reduce restrictions to trade in tourism (Objective 3), it was suggested that limitations on market access and national treatment were to be eliminated. No specific details were provided. These shortcomings suggest the absence of tourism expertise in the policy-making process and proper management accountability. A long-term strategic plan and a regional investment blueprint defining the future direction of tourism development in the region are needed to improve the situation.

It is clear that factors associated with the progress of ASEAN tourism are much more complex than ill-defined objectives or bad management. Intergovernmental collaboration is political in nature and so further examination is required to identify the issues facing ASEAN tourism; these are examined in the next section where a new 
approach to analyzing intergovernmental collaboration is presented. The approach enables better identification of the factors that have facilitated or hindered progress on the ASEAN Roadmap, and which can be employed in policy formulation.

\subsection{Facilitators and inhibitors of ASEAN tourism collaboration}

A number of studies in the literature explore the conditions for successful collaboration between different parties. The authors have identified three general factors, namely: (1) the degree of stake each party holds, (2) the competency of the stakeholders to carry out the agenda, and (3) the willingness of them to do so. They are explained in detail below.

Vangen and Huxham (2003:5-6) suggest that the aim of collaboration, under most circumstances, is "to deal more effectively with major issues that sit in the organizations' inter-organizational domain and that cannot be tackled by any organization acting alone". Depending on the degree of stake involved, the degree of commitment from stakeholders, and thus the chance of success of the collaboration, may vary (Freeman, 1984). For example, if a substantial investment or the reputation of the organizations is at stake, the collaboration plan is likely to receive much attention from the stakeholders. 
The second factor relates to the competency of an organization and its personnel to manage the process externally with their counterparts as well as internally within their organization. The success of collaboration begins with a good plan. Thus, good strategic planning and organization skills are required from the top management involved. They must also have expertise in handling interorganizational relationships. In terms of internal governance, management skills such as deployment of resources and leadership are essential to execute the collaboration plan within each organization (Zollo et al., 2002).

Third, the willingness to engage oneself to the process and to implement what is planned can be regarded as a relational factor. It is independent of the first two factors, that is to say, collaboration between two parties with a weak or negative relationship may not be carried out (as planned) even if they are competent to do so and high stake is involved. Polonsky et al. (2002) propose that stakeholder relationships depend on the amount of trust, past and current interactions, power relations, commitment and the common interests among stakeholders. Husted (1994), using a transaction costs and social networks perspective, offered similar conclusion but adds that the degree of 
cooperation would increase when there is more than one link between the parties involved (e.g. in ASEAN, countries collaborate in more than one economic sector), if they share similar values, and when potential cooperation is expected in the future.

While the authors do not disagree with these views, they somewhat limit the potential to discover other possible success factors because of their specificity. Indeed analyses of the case findings pointed to an alternative approach, which involves the study of three dimensions of collaboration: stakeholders, resources, and processes and mechanisms. As the following analysis illustrates, this approach helps uncover facilitating and inhibiting factors which have not been fully addressed in the literature, and which are very relevant to an understanding of tourism collaboration in ASEAN.

\subsubsection{Stakeholders}

The role played by key stakeholders was most talked about by the interviewees, both as a facilitating and a hindering factor. Stakeholders facilitated ASEAN tourism in three ways:

a) Political will and support from national leaders

b) The trust built among tourism policy-makers over years of working together 
c) Sub-regional collaboration, especially in the Greater Mekong Subregion (GMS)

Political will and support from national leaders

Ten countries of different cultural background and various stages of development working together is a challenging task. ASEAN tourism collaboration remained insignificant until 1997/8, when the region was hit by the Asian Financial Crisis. It was again stepped up after the tragic events of $9 / 11$ and 2002 Bali bombing, with the launch of the ASEAN Tourism Agreement in 2002. As Wong et al. (in press) argue, the milestones achieved so far were fuelled by support from national leaders or economic ministers - first with signing the 2002 Agreement, then identifying tourism as a priority sector, and introducing the Roadmap in 2004. As the following respondent commented, political will from the top of the hierarchy is very important.

"We are doing this strategy, because the Prime Ministers decided in the summit that tourism should be one of the areas for regional cooperation. So that is where the commitment comes. At a very high level, the commitment is already there. The Prime Ministers decide yes, this is important." (International organization representative)

This is consistent with much of the literature, which suggests that the degree of willingness to engage oneself to collaboration would determine how successful the relationship is (Polonsky et al., 2002; Husted, 1994). However, as we later discuss, the 
study of the political environment of ASEAN tourism needs to be stratified because the dynamics on the different levels of government have different impact on the collaborative process. On the national level, there are forces that facilitate, but on the sectoral and departmental levels, there are deterring factors such as competition among members and the lack of a collaborative mindset. In other words, the high level pronouncements made which promise greater collaboration do not necessarily translate to actions because collaboration is sometimes perceived as compromises that impinge on national interests or autonomy. The deterring factors are to be discussed in-depth.

\section{Trust among tourism policy-makers}

Apart from political will, we found that the trust built among tourism policy-makers over years of working together is an important facilitating factor. Two interviewees who have long time experience working in GMS said it took the member states (five out of six of which are ASEAN members) ten years to build trust among each other. With a decade of experience, GMS is now ready to step up their collaboration in tourism with the help from ADB by implementing a new ten-year strategic plan.

"Once the trust has been established, once it has been demonstrated that people can work together, and one or two or three projects have worked, let's look in a more comprehensive way." (International organization representative, commenting on GMS tourism cooperation) 
The same principle may apply to ASEAN tourism. Although the member states only have few years of actual experience cooperating, mutual understanding and predictability has built up over the years. To some interviewees, these two elements are catalysts that speed up the collaborative process.

"People [tourism officials] sometimes talk, not only on a formal basis during a meeting, but outside the meeting also they talk to each other. Even something that is really personal, and this atmosphere has contributed to the achievement of the objective of each meeting, because ... officials from one country to another could easily understand on the mission being carried by each country in pursuing the cooperation.” (International organization representative)

The trust and friendship built over years have clearly enhanced the level of trust, cohesion and communication among the tourism policy-makers. At the same time, the cooperative experiences accumulated and the mutual understanding developed have enriched the political culture on a sub-national level, and ultimately, facilitated tourism collaboration.

"At the ATF level people forge friendship, links and all that, and that enables you to be more collaborative." (Malaysia government official)

This is in line with Polonsky et al. (2002) who propose that stakeholder relationships 
partly depend on the amount of trust and past interactions.

\section{Sub-regional collaboration}

In addition to national leaders' commitment and trust among tourism policy-makers, the work undertaken on a sub-regional level must not be ignored. Funded by the Asian Development Bank (ADB), the Greater Mekong Subregion (GMS) project has six member states: Cambodia, Laos, Myanmar, Vietnam (a.k.a. CLMV), Thailand and China. All except China are members of ASEAN, with CLMV being the least developed countries in the ASEAN region. One of the most important contributions of GMS to ASEAN is that, through GMS projects, there is an opportunity to narrow the development gap between the more developed and less developed member states in ASEAN. Such gap, as later discussed, is considered to be a major hindering factor to ASEAN tourism collaboration. The ADB-GMS projects help those less developed countries enhance their tourism infrastructure and development capability. One example is their human resources development and capacity building project aims to raise the standard of professionalism for public officials, NTO personnel and vocational schools (ADB, 2005). This is one of the projects being implemented under the 2006-2010 GMS Tourism Sector Strategy.

“The ten ASEAN destinations can definitely benefit from this [GMS] 
because I think that some of the destinations that are being activated through this Mekong sub-regional activity are the very destinations that are still ... the least developed tourism infrastructure at this point." (Industry association representative)

This indicates that a separate agency can contribute indirectly by providing additional resources. The dynamics between sub-regional and a wider regional collaboration are not yet adequately addressed in the literature.

Although national governments and tourism policy-makers have contributed to the ASEAN tourism collaboration process in some ways, they also created obstacles. Our investigation suggested that stakeholders can create barriers to collaboration in at least five ways:

a) Maintaining control and changing priorities

b) Territoriality in individual government

c) Lack of a collaborative mindset

d) Competition among members

e) Lack of private sector involvement 


\section{Maintaining control and changing priorities}

In the 2002 ASEAN Tourism Agreement, one of the objectives is to facilitate travel into and within the region. As previously reported, what has been achieved so far is the signing of the 2006 Visa Exemption Framework Agreement, which allows ASEAN nationals to travel within the region without a visa. Yet, the goal of facilitating visa procedures for international travelers has not been realized. The findings attribute the lack of progress to the reluctance of governments to relinquish control in areas that are sovereignty-related. The collaboration agenda is politicized.

"No one is too enthusiastic about visa harmonization because they want to have their own control over immigration." (International organization veteran)

The desire to maintain control and power has led to a decrease in willingness to collaborate. Despite the fact that visa facilitation and the subsequent increase in tourist flow are of common interests to all members, the political nature of regional tourism has slowed down the collaboration process. As Timothy (2003) recorded in his study on supranationalist alliances, the reluctance of countries to relinquish absolute control in some areas as a political hindrance to cooperation. 
The political environment for ASEAN tourism is also influenced by the change of government, tourism minister, or management of national tourism organizations (NTOs). Such changes could mean a shift in priorities of individual country. This could deter the progress of certain policy implementation.

"Some of these [hindering] factors are possibly the change of government ...with new governments coming in, there could be new economic agenda." (Singapore government official)

Applying Powell's (1994:341) concept of regime resilience, the change of priorities due to the change of leadership reflects the need for ASEAN tourism to be more resilient as a regime, so that its "collective decision and behavior" are not easily influenced by those changes.

Barriers to inter-agency coordination

Another issue identified on a national level is the lack of coordination among government agencies. Tourism is a sector that requires the cooperation of multiple government departments. While there is, in all states, a ministry or department that coordinates tourism-pertinent matters, other government bodies such as immigration, aviation, international trade, and forestry and national parks also play a part in tourism development. Often, these departments consider tourism as an external matter to their 
established territory. Communication and work between the tourism department and their counterparts are sometimes obstructed by red tapes and bureaucratic culture.

“... [for example] transport ministries will never willingly accede to discussion of transport issues to a tourist cooperation forum, and yet ...if you can't discuss transport, are you really having a discussion about tourism?... it restricts the amount of cooperating you can do at an intergovernmental level." (Academic)

Thus, even if the tourism ministers are totally committed to regional tourism collaboration, without the cooperation of their counterparts in their own countries over whom they have little control, ASEAN tourism is hard to make good progress.

We mentioned previously that the study of the political environment of ASEAN tourism should be stratified because the dynamics on the different levels of government have different impact on the collaborative process. We can see from this piece of findings that the commitments made on the national level (e.g. Agreement, Roadmap) do not translate to smooth policy implementation on the departmental level. With the involvement of multiple agencies within each member states, the collaborative arena for ASEAN tourism becomes highly complex and political. 


\section{Lack of a collaborative mindset}

In spite of the trust and friendship developed among the tourism policy-makers over the last few years, some respondents feel that there is still a lack of a collaborative mindset in some part of the collaboration. One may argue that it is a problem in itself, but the authors believe it is more of a symptom of other problems. For example, two government officials from Cambodia and Indonesia respectively pointed to the example where Singapore had decided not to join the common competency standards scheme as they already had a similar system in place. On one hand, to some members, Singapore's action showed a lack of collaborative spirit. On the other hand, it could be seen as a problem of development gap between the more developed and less developed members.

Another example given by an Indonesian interviewee was related to marketing. It had been agreed that the ASEAN logo should be included in all promotional materials of all member countries. Unfortunately, not all countries have fulfilled their obligation.

"But when you come to the facts, none of them put the logo. So ... when it comes to commitment, not every country is committed because it's already become competition.”

The Visit ASEAN Pass (formerly known as Hip Hop Pass) program also failed to deliver. The Pass, which involved packages of hotel and air tickets, aimed to promote 
the region as one destination and to encourage intra-regional travel. In 2007 , only about 8,000 passes were sold while arrivals were measured in the magnitude of millions.

We argue that the lack of commitment can be explained by rivalry among members, even though cooperative behavior can result in win-win outcomes.

We conclude from this that researchers should not take factors such as reluctance to collaborate, or lack of commitment on their face value but try to uncover the cause so as to provide a more accurate explanation.

\section{Competition among members}

Competition is a counteracting force to cooperation. Yet they often co-exist. The problem is best illustrated in the marketing domain. Some respondents commented that the idea of 'ASEAN as a single destination' (Agreement objective 5) is little more than a political gesture.

"We are a single destination but at the same time we are also competitors, so that's why in terms of being a single destination it's nothing more than the image that needs to be promoted for ASEAN, showing that we stick together." (Indonesia government official) 
The contest for tourism business within the region is inevitable. Because of its size, one cannot expect even long-haul travelers to tour the whole region in one trip. While the authors agree that promoting ASEAN as a single destination is somewhat counter-intuitive from a marketing perspective, competition should not become a deterrent to other parts of the collaborative agenda.

\section{Lack of private sector involvement}

Private sector stakeholders can potentially play an important role in ASEAN tourism collaboration. Not only could it be a source of financial support to many collaboration projects, but also due to the fact that tourism is an industry-driven sector, it can be an execution arm for policy implementation. Unfortunately, private sector involvement both within and outside the ASEAN institutional structure is limited.

Within the ASEAN institutional structure, ASEANTA (ASEAN Tourism Association) is the official body representing the tourism private sector. Half of their members are national trade associations and airlines. According to their representative, the only way the Association is involved in ASEAN tourism collaboration is its participation in the marketing task force. He added that they have little say at the meetings:

"Usually they [attendees in the task force meetings] are governments 
except for ASEANTA ... So it is like ten voices against one, so you can imagine what is the situation. But at least the private sector is represented in the meeting, as opposed to previously, nobody in the private sector are allowed to sit inside." (ASEANTA representative)

Outside the ASEAN institutional structure, regional public-private sector cooperation is still much limited. Despite ASEAN's various initiatives in attracting foreign investment, including the ASEAN Investment Area (AIA) scheme, a project consultant expressed that the poor legal and financial systems, the lack of infrastructure and quality manpower, and security concerns particularly in CLMV, have discouraged private sector's involvement.

We have seen in the case of ADB-GMS how a separate entity can indirectly contribute to ASEAN tourism by supporting the less-developed members. We believe that the travel industry can also make significant contributions by, for example, offering expert advice and resources for policy implementation. A public-private partnership needs to be established.

\subsubsection{Resources}

The second dimension of collaboration examined in an attempt to uncover factors that 
facilitated and hindered ASEAN tourism was 'resources'.

Resources here refer to both financial resources and human capital. It was widely perceived among the respondents that the lack of expertise and financial support are major obstacles to progress in meeting the objectives of the Tourism Agreement. In the key coordinating body, ASEAN Secretariat for example, there is only one full-time technical officer looking after the tourism sector. This person reports to two more senior officials who are responsible for several economic sectors. This team is apparently too small to coordinate a policy agenda that entails various policy areas (e.g. marketing, human resources development, visa policies, tourism investment, etc.) in ten countries.

"In addition to our role in facilitating the tasks of ASEAN tourism cooperation, we also have to be an expert, although... I'm not an expert in manpower, I'm not really an expert in marketing, but sometimes we have to be the expert for this purpose. And ASEAN Secretariat has a limited number of staff, so we have difficulties, particularly for those [countries] who are still relying on us.” (ASEAN Secretariat representative)

Funding for ASEAN tourism mainly comes from the member states. The amount of funding is limited because, based on the principle of equal contribution, all member countries contribute the same amount of money annually to fund the approved ASEAN programs/activities. In other words, the total amount of funding depends on how much 
the less-developed nations can afford or willing to pay. At this stage, contribution from those members is limited. As one respondent pointed out, some initiatives such as organizing an ASEAN Tourism Area in international tourism fairs or production of televised promotional clips have not been carried out effectively because of limited finance.

The impact of the lack of funding can also be illustrated by the closure of the ASEAN Information Center. The Center was established in 1988 to coordinate ASEAN tourism projects and to provide technical assistance to members to implement those projects. The dedicated resources and expertise would have greatly facilitated the collaboration. Unfortunately, due to the lack of funding, the Center was closed down in 1996 (Source: ASEAN Secretariat representative).

The paucity of resources is also an issue on the country level. The less-developed members in particular often do not have the capability to implement and execute ASEAN projects/policies.

"Cambodia said 'yeah, we fully support this and we'd like to see it happen'; but they didn't have any institutional capacity to really push it." (International organization representative) 
The situation is ameliorated by the technical and financial assistance provided by ASEAN's dialogue partners. Their contributions have been much welcomed by the members. One example is the ASEAN-Japan Center established by the Japanese government in 1981 to promote trade, investment and tourism between the two parties. Japanese language training was offered to ASEAN tour operators, and there were marketing initiatives that brought ASEAN tourism products to Japan and showcased them in local travel marts. As for other dialogue partners, Australia and the European Union have provided consultancy services and financial support to ASEAN. An ASEAN-Australia Economic Cooperation Program was first started in 1974, now known as the ASEAN Australia Development Cooperation Program. A part of the program offers funding for ASEAN tourism research.

The role played by the dialogue partners is yet another illustration of how entities external to ASEAN can facilitate tourism collaboration in the region. ASEAN should seek to strengthen its partnership with those countries, and to increase the capacity of its coordinating body, the ASEAN Secretariat. As the literature suggests, competent stakeholders are keys to successful collaboration (Zollo et al., 2002). 


\subsubsection{Processes and mechanisms}

The third dimension of collaboration examined was processes and mechanisms. It was found that the unique political culture developed over the years in ASEAN, the so-called 'ASEAN Way' (see also Acharya, 2000), has helped facilitate the tourism collaborative process. This can be illustrated by the 'ASEAN minus X' (ASEAN-X) principle, which provides flexibility in implementing collaborative projects. Flexibility means that if two or more countries are ready to implement certain policies or strategies, they should proceed without waiting for those that are not. The interviewees believe that ASEAN tourism collaboration would have been slowed down substantially if this approach were not adopted.

“... the ASEAN-X approach is actually a relief for ASEAN member countries, especially for those who want to move forward. For those who are not ready, then okay you can join later because now we want to move up to this." (ASEAN Secretariat representative)

Another policy approach adopted that was deemed beneficial was called the 'conservative progressive' approach. That is, when starting a new area of collaboration, a small number of issues that are of high common interests to all members are identified. Pilot projects will then be undertaken addressing these issues. If successful, more projects will be developed using the pilots as models. The common competency 
standards project, for example, was one of the first to address the human resources development objective (Objective 6) in the 2002 Agreement. This approach allows confidence to be built progressively among policy makers who might be concerned about the economic and/or political outcome of the new policy. Moreover, for an institution with limited resources available, the risks of venturing into a new area could be reduced by experimenting on a small scale before fully implementing a policy.

The pragmatic orientation adopted by ASEAN tourism policy-makers is particularly relevant to collaborative relationships that involve a large number of stakeholders who come from different background and vary in terms of amount of resources available to them. Little has been written about these policy implementation approaches. Their effectiveness and implications are still to be explored.

We identify two hindering factors in the aspect of processes and mechanisms. The first one is related to the dilemma in the cooperation agenda created by the development gap, and the other related to the institutional diversity within the region.

Table 1 shows the GDP per capita of each member state and the disparities of wealth in 
the region. According to the 2008 statistics, Myanmar had the lowest GDP per capita of USD 464, and Singapore USD 38,046 (ASEAN, 2009b). The development gap between the less- and more-developed nations does not only lead to resources issues as we previously discussed, it also creates problems in maintaining a fair cooperative agenda for all member states. A project that may seem to benefit the whole region in reality may not be beneficial to all. For example, when it comes to liberalizing movement of tourism workers in the region, small nations such as Brunei and Singapore may not benefit as much as countries such as Indonesia, which has a population at least fifty times bigger. In the case of introducing an ASEAN visa, the less-developed countries may lose a source of income generated from visa issuance as visitors are likely to get their visas from countries where immigration procedures are better established. Questions also arise in marketing. Do equal contributions from members translate to equal benefits? Since all member states are at different stage of market saturation or destination maturity, would a significant proportion of contribution from a more mature member such as Thailand be eventually channeled to the younger, more mysterious destinations like Myanmar or Laos?

Thus, creating and maintaining a fair cooperative agenda for all ASEAN states is a 
delicate process. It requires thorough consideration of interests of all parties, open communication, sensitivity, and respect. These properties need to be embedded in the tourism policy-making mechanism for successful regional collaboration.

For ASEAN, diversity is the raison d'être but can also be a source of problems. The great diversity in the nature of political institutions of member states poses challenges to the general collaborative mechanism. To begin with, there are differences in ideology capitalism vs. communism, and a Buddhist monarchy vs. a military regime. Each government places various degrees of emphasis on tourism and adopts a different approach to tourism development. There are also differences in institutional structure for tourism. For example neither Laos nor Singapore has a separate ministry of tourism. At ministerial meetings, they are represented by ministers from the Prime Minister's office and the Ministry of Trade and Industry respectively. They may have higher level of political power in their own government than their counterparts, i.e. tourism ministers of other countries who are usually junior ministers. This may lead to an imbalance of negotiating power in ministerial meetings, and subsequently, issues in collective decision-making. 
Diversity is the nature of ASEAN collaboration. It creates problems, but at the same time, provides an environment for mutual learning. Members should look beyond and persevere through the challenges and try to make the most out of this working relationship.

In summary, in our study of facilitating and hindering factors for ASEAN tourism, we found that the empirical findings are largely congruous with the three factors suggested in the literature, namely (1) the degree of stake each party holds (Freeman, 1984), (2) the competency of the stakeholders to carry out the agenda (Zollo et al., 2002), and (3) the willingness of them to do so (Polonsky et al., 2002; Husted, 2004). However, by using the three-dimension approach, i.e. stakeholders, resources, and process and mechanisms, we realized that the collaboration phenomenon is very complex which existing theories cannot fully explain. We uncovered how entities external to ASEAN, such as ADB-GMS, dialogue partners, and potentially the private sector, can contribute by improving the competency of some stakeholders. We also found that the pragmatic orientation adopted by ASEAN in policy implementation has played a facilitating role. Finally, we understand the importance of study the political environment in a stratified manner because the dynamics on the different levels of government have different 
impact on the collaborative process - facilitating on the national level, deterring on the sectoral and departmental levels. These findings indicate that the boundaries of existing theories require expansion.

Figure 1 presents a framework for analyzing intergovernmental collaboration. It dissects the facilitators and inhibitors of ASEAN tourism along three dimensions: stakeholders, resources, and processes and mechanisms.

(Insert Figure 1 here)

\section{Policy recommendations to strengthen ASEAN tourism collaboration}

Based on the above findings and existing theories, we propose some key measures to ASEAN with the aim to strengthen and expedite its tourism collaboration.

\subsection{Resources}

We believe the first and foremost action that needs to be taken is to strengthen the capacity of the tourism division in the ASEAN Secretariat. The Secretariat is like a conductor in an orchestra. It plays a crucial role in coordinating and monitoring the 
collaboration. Its competency holds the key to ASEAN's success. More officers with adequate level of knowledge in tourism are urgently needed if ASEAN is committed to realize the 2015 ASEAN Economic Community vision.

We acknowledge that obtaining funding to finance this capacity building exercise may be difficult given the economic challenges facing some member countries. In order to secure additional financial and technical support, ASEAN tourism should continue to build on its existing partnership with Japan and Australia, and seek to establish new relationships with potential partners such as China, which is already a dialogue partner of ASEAN.

\subsection{Stakeholders}

As the literature suggests, the higher the degree of stake, the more likely the collaboration will be successful (Freeman, 1984). Thus, the efforts to demonstrate strong political will towards ASEAN tourism and to promote a collaborative mindset must continue at all levels of government. The most meaningful way for national leaders to demonstrate their commitment is by committing more resources to the various ASEAN tourism projects. The message of the importance of ASEAN economic 
integration should also be communicated regularly to all government bodies involved, because the collaboration will only succeed if the policy-makers and executives believe in the ASEAN vision

With evidence showing how external entities can contribute to ASEAN tourism, we believe the private sector should become more involved. After all, tourism is an industry-driven economic sector. It takes a strong and entrepreneurial private sector to develop a competitive tourism industry across the region. Governments should 'activate' the spirit of the industry by inviting for their input in policy-formulation, especially in the areas of marketing (Agreement objective five), human resource development (objective six), and investment (objective seven). The industry can also act as an executive arm for policy implementation, and possibly provide financial and technical support to the collaborative projects.

\subsection{Processes and mechanisms}

As pointed out in our assessment of ASEAN's progress in tourism collaboration, there are a number of ill-defined objectives and measures. A long-term strategic plan with clear and specific goals is needed. Deadlines of numerous overdue measures should be 
revised, coupled with a strong monitoring and evaluation mechanism. Completion of these tasks will very much depend on prompt actions by the ASEAN Secretariat in strengthening the capacity of its tourism division.

Table 3 summarizes the key findings of this paper. The factors that facilitated and hindered ASEAN tourism as well as the respective policy recommendations are listed in columns. They are then categorized into the three dimensions of collaboration listed on the left, namely, stakeholders, resources, and processes and mechanisms.

(Insert Table 3 here)

\section{Conclusions}

This paper aimed to provide an overall assessment of the progress made by ASEAN tourism, identify the facilitators and inhibitors, and provide policy recommendations to strengthen the collaboration. It was found that many of the suggested measures in the action plan, Roadmap for Integration of Tourism Sector, were either not implemented at all or overdue, although relatively significant progress was made in travel facilitation and human resources development. 
A range of factors influenced the progress made by ASEAN, which collectively expand the boundaries of existing literature. These factors can be categorized into three dimensions of collaboration: stakeholders, resources, and processes and mechanisms. Along the resources dimension, for example, we identified that the financial and technical support rendered by the dialogue partners have been instrumental to assisting the less-developed members, but the lack of financial resources and expertise in the ASEAN Secretariat has slowed down the overall collaborative process. To expedite and improve the collaboration, more officers with adequate level of knowledge in tourism are urgently needed in the ASEAN Secretariat, so that in turn, a strong monitoring and evaluation mechanism can be in place.

Given the paucity of studies in ASEAN tourism, this paper serves as a starting point to improve our understanding of the phenomenon and the ingredients of its successes and failures. ASEAN tourism operates in a specific and complex context. Existing theories cannot always provide a complete explanation. For example, our findings show how entities external to ASEAN, such as ADB-GMS, dialogue partners, and potentially the private sector, can contribute by improving the competency of some stakeholders. We 
also found that the pragmatic orientation adopted by ASEAN in policy implementation has played a facilitating role. These issues are yet to be fully addressed in the literature. The boundaries of existing theories thus need to be expanded.

The paper also provides suggestions to policy-makers for improving current collaboration, which in turn has the potential to enhance the contribution of tourism to regional social and economic development. Further research should focus on developing more concrete strategies for improving policy implementation, and theorizing regional collaboration in specific economic sectors. Future research could also attempt a comparative study with similar supranational organizations such as the European Union identifying similarities and differences in terms of indirect and direct preconditions, approach to policy-making, and factors involved in the process of formulating the tourism policy framework. After all, the distinct influences on collaboration in tourism, in contrast to other industry sectors, remain unclear in the literature.

As ASEAN members evolve in their political, social and economic development alongside variations in the global economic environment and dramatic events, so too will the nature of their tourism collaboration. The formation and early progression of 
such collaboration does not easily fit any textbook prototype and this paper has provided the framework through which future development can be observed, analyzed and monitored. This constitutes a significant step in our understanding of what clearly is a dynamic phenomenon. 
Table 1: Contribution of travel and tourism to ASEAN members' GDP

\begin{tabular}{|l|l|l|l|}
\hline Country & $\begin{array}{l}\text { GDP per capita (2008 } \\
\text { estimates) (USD, in current } \\
\text { prices) }\end{array}$ & $\begin{array}{l}\text { Contribution of travel and } \\
\text { tourism to GDP (2009 } \\
\text { estimates) (\%) }\end{array}$ & $\begin{array}{l}\text { Real GDP growth for the } \\
\text { travel and tourism } \\
\text { economy (from 2009 to } \\
2010 \text { estimates) (\%) }\end{array}$ \\
\hline Brunei & 35622 & 11.5 & 0.9 \\
\hline Cambodia & 756 & 17.5 & -2.0 \\
\hline Indonesia & 2236 & 7.8 & 0.1 \\
\hline Laos & 917 & 10.8 & -1.2 \\
\hline Malaysia & 7991 & 12.3 & -5.1 \\
\hline Myanmar & 464 & 6.5 & 1.8 \\
\hline Philippines & 1843 & 8.7 & -2.6 \\
\hline Singapore & 38046 & 7.3 & -10.2 \\
\hline Thailand & 4116 & 14.7 & -3.3 \\
\hline Vietnam & 1052 & 13.1 & 0.2 \\
\hline ASEAN & $\mathbf{2 5 8 1}$ & $\mathbf{1 1 . 0}$ & $-\mathbf{2 . 1}$ \\
\hline
\end{tabular}

${ }^{1}$ Source: ASEAN (2009b). Selected basic ASEAN indicators. Retrieved from http://www.aseansec.org on 15 August 2009.

${ }^{2}$ Source: WTTC (2009). The 2009 Travel \& Tourism Economic Research. Retrieved from http://www.wttc.org on 15 August 2009. 
Table 2: Achievement of the ASEAN Tourism Agreement objectives

\begin{tabular}{|c|c|c|c|c|}
\hline \multirow[b]{2}{*}{ Themes } & \multirow{2}{*}{$\begin{array}{l}\text { ASEAN Agreement Objectives } \\
\text { (Numbering follows that in the original } \\
\text { agreement) }\end{array}$} & \multicolumn{3}{|c|}{ Achieved? } \\
\hline & & Yes & No & Progressing \\
\hline \multirow{3}{*}{$\begin{array}{l}\text { 1. To liberalize the } \\
\text { flow of money and } \\
\text { people }\end{array}$} & $\begin{array}{l}\text { i) To cooperate in facilitating travel into and } \\
\text { within ASEAN }\end{array}$ & & & $\begin{array}{c}\sqrt{ } \\
\text { (Visa Exemption } \\
\text { Framework Agreement } \\
\text { signed in 2006) } \\
\end{array}$ \\
\hline & $\begin{array}{l}\text { iii) To substantially reduce restrictions to } \\
\text { trade in tourism and travel services among } \\
\text { ASEAN member states }\end{array}$ & & $\sqrt{ }$ & \\
\hline & $\begin{array}{l}\text { vii) To create favorable conditions for the } \\
\text { public and private sectors to engage more } \\
\text { deeply in tourism development, } \\
\text { intra-ASEAN travel and investment in } \\
\text { tourism services and facilities }\end{array}$ & & & $\begin{array}{c}\sqrt{ } \\
\text { (Investment Forum } \\
\text { started in 2005 but no } \\
\text { concrete outcome) }\end{array}$ \\
\hline \multirow{2}{*}{$\begin{array}{l}\text { 2. To increase the } \\
\text { competitiveness of } \\
\text { the tourism } \\
\text { industry }\end{array}$} & $\begin{array}{l}\text { ii) To enhance cooperation in the tourism } \\
\text { industry among ASEAN member states in } \\
\text { order to improve its efficiency and } \\
\text { competitiveness }\end{array}$ & & $\sqrt{ }$ & \\
\hline & $\begin{array}{l}\text { vi) To enhance mutual assistance in human } \\
\text { resource development and strengthen } \\
\text { cooperation to develop, upgrade and expand } \\
\text { tourism and travel facilities and services in } \\
\text { ASEAN }\end{array}$ & & & \begin{tabular}{|c}
$\sqrt{ }$ \\
(Common Competency \\
Standards finalized in \\
2008)
\end{tabular} \\
\hline \multirow{2}{*}{$\begin{array}{l}\text { 3.To strengthen the } \\
\text { unity and identity } \\
\text { of ASEAN as a } \\
\text { region, }\end{array}$} & $\begin{array}{l}\text { iv) To establish an integrated network of } \\
\text { tourism and travel services in order to } \\
\text { maximize the complementary nature of the } \\
\text { region's tourist attractions }\end{array}$ & & $\sqrt{ }$ & \\
\hline & $\begin{array}{l}\text { v) To enhance the development and } \\
\text { promotion of ASEAN as a single tourism } \\
\text { destination with world-class standards, } \\
\text { facilities and attractions }\end{array}$ & & & $\begin{array}{c}\sqrt{ } \\
\text { (Joint promotion in trade } \\
\text { shows started in } 2006 \text { but } \\
\text { no concrete outcome) }\end{array}$ \\
\hline
\end{tabular}


Table 3: Summary of factors and recommendations for ASEAN tourism collaboration

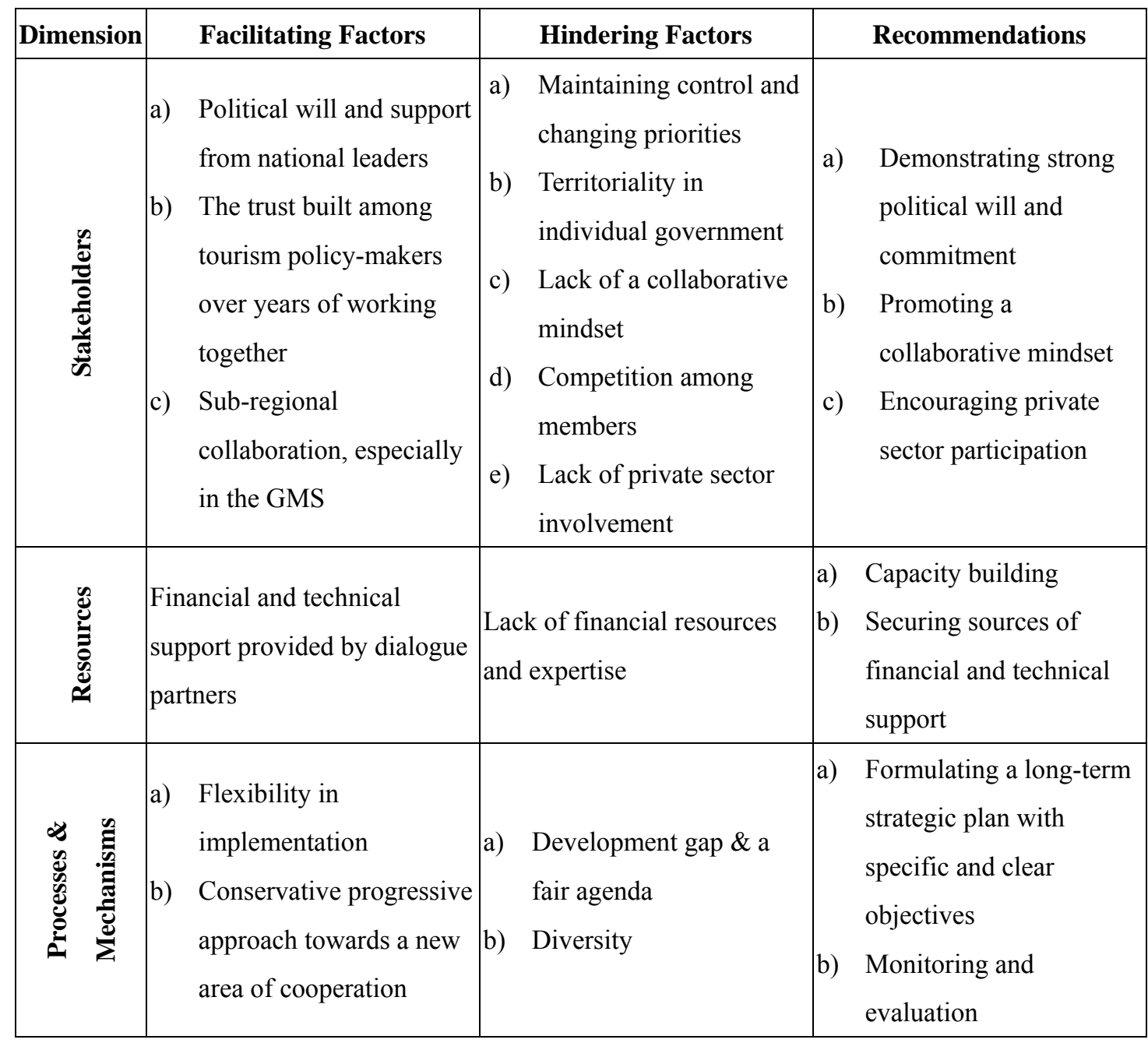


Figure 1: A framework of intergovernmental collaboration - facilitators and inhibitors of ASEAN tourism

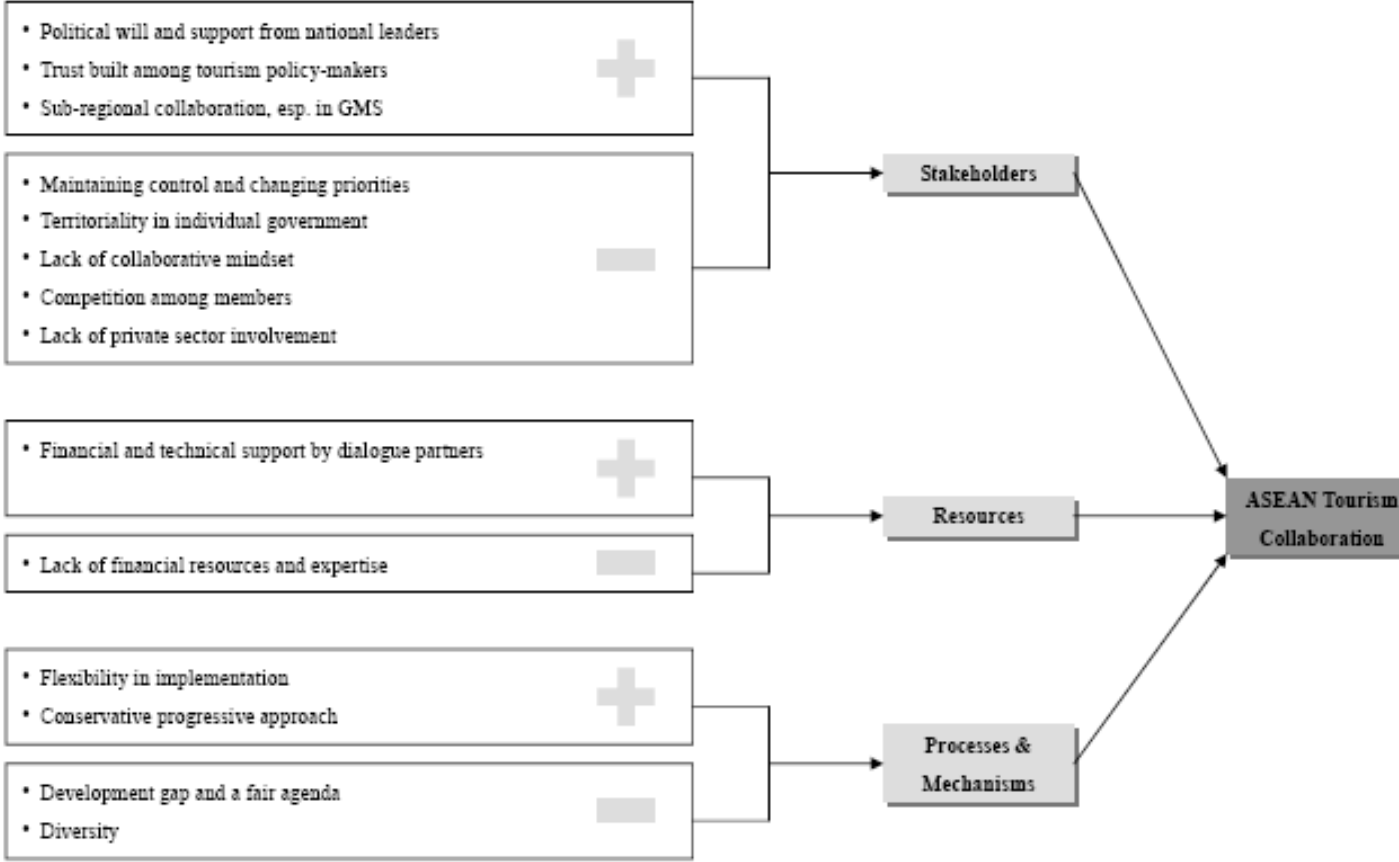




\section{References:}

Acharya A. (2000). Constructing a Security Community in Southeast Asia. New York: Routledge.

ADB (2005). Greater Mekong Subregion Tourism Sector Strategy. Manila: ADB.

ASEAN (2002). ASEAN Tourism Agreement. Jakarta: ASEAN Secretariat.

ASEAN (2006). Joint Media Statement of the Thirty-Eight ASEAN Economic Ministers' (AEM) Meeting. 22 August 2006. ASEAN Press Release. Kuala Lumpur.

ASEAN (2009a). Tourist arrivals in ASEAN. Retrieved from http://www.aseansec.org on 15 August 2009.

ASEAN (2009b). Selected basic ASEAN indicators. Retrieved from http://www.aseansec.org on 15 August 2009.

Freeman R.E. (1984). Strategic Management: A Stakeholder Approach. Marshfield: Pitman.

Hasenclever, A., Mayer, P., Rittberger, V. (1997). Theories of International Regimes. Cambridge: Cambridge University Press.

Husted B.W. (1994). Transaction costs, norms, and social networks. Business and Society, 33(1), 30-57.

Lincoln Y.S, Guba E.G. (1985). Naturalistic Inquiry. Beverly Hills: Sage Publications Inc.

Powell, R. (1994). Anarchy in international relations theory: the neorealist-neoliberal debate. International Organization, 48:313-344.

Polonsky, M.J., Schuppisser, D.S.W., Beldona, S. (2002). A stakeholder perspective for analyzing marketing relationships. Journal of Market-Focused Management, 5(2), 109-126. 
Tan G. (2003). ASEAN Economic Development and Cooperation (3rd ed.). Singapore: Times Academic Press.

Timothy D.J. (2003). Supranationalist alliances and tourism: insights from ASEAN and SAARC. Current Issues in Tourism, 6(3), 250-266.

UN-World Tourism Organization (2000). Tourism 2020 Vision - Volume 3 East Asia and the Pacific. Madrid: World Tourism Organization.

UN-World Tourism Organization (2003). UNWTO World Tourism Barometer (January 2003). Madrid: World Tourism Organization.

UN-World Tourism Organization (2008). UNWTO World Tourism Barometer (January 2008). Madrid: World Tourism Organization.

Underdal, A. (1992). The concept of regime effectiveness. Cooperation and Conflict, 27: 227-240.

Vangen, S., Huxham, C. (2003). Nurturing collaborative relations: building trust in interorganizational collaboration. The Journal of Applied Behavioral Science, 39(1), $5-31$.

Wong, E.P.Y., Mistilis, N., Dwyer, L. (In press). Understanding ASEAN tourism collaboration - The preconditions and policy framework formulation. International Journal of Tourism Research.

WTTC (2009). The 2009 Travel \& Tourism Economic Research. Retrieved from http://www.wttc.org on 15 August 2009.

Yeh R.S. (2002). Association of South-East Asian Nations. In M. Warner (Ed.), International Encyclopedia of Business and Management (1, 296-299). London: Thomson Learning.

Yin R.K. (2003). Case Study Research: Design and Methods (3rd ed.). Sage Publications: Thousand Oaks.

Young, O.R. (1994). International Governance Protecting the Environment in a 
Stateless Society. Ithaca: Cornell University Press.

Zollo, M., Reuer, J.J., Singh, H. (2002). Interorganizational routines and performance in strategic alliances. Organization Science, 13(6), 701-713. 